\title{
TOTAL BAKTERI ASAM LAKTAT ISI RUMEN KERING DAN SEGAR SEBAGAI INOKULAN DALAM PEMBUATAN SILASE
}

\author{
Total of Lactic Acid Bacteria on Dried and Fresh Rumen Content as Inoculant \\ For Ensiling Process \\ Anifiatiningrum*1), Marjuki $^{2)}$ dan Siti Chuzaemi ${ }^{2)}$ \\ ${ }^{1)}$ Mahasiswa Fakultas Peternakan, Universitas Brawijaya Jalan Veteran, Ketawanggede, Kec. Lowokwaru, \\ Kota Malang, Jawa Timur, Indonesia 65145 \\ ${ }^{2)}$ Dosen Fakultas Peternakan, Universitas Brawijaya Jalan Veteran, Ketawanggede, Kec. Lowokwaru, \\ Kota Malang, Jawa Timur, Indonesia 65145 \\ E-mail: ningrumanifiati@gmail.com \\ Diterima Pasca Revisi: 27 Februari 2020 \\ Layak Diterbitkan: 1 Maret 2020
}

\begin{abstract}
ABSTRAK
Penelitian ini bertujuan untuk mengetahui keberadaan BAL yang terkandung pada isi rumen yang dikeringkan dengan pengamatan total BAL isi rumen segar dan isi rumen kering. Isi rumen sapi diambil dari 8 ekor sapi yang diambil isi rumennya setelah itu dicampur (dikomposit) secara homogen dari 8 ekor sapi tersebut. Variabel yang diamati adalah total $B A L$ isi rumen segar dan isi rumen kering. Total BAL isi rumen segar dalam penelitian ini tidak memiliki perbedaan yang signifikan terhadap total BAL isi rumen kering, dikarenakan di dalam isi rumen kering masih terdapat bakteri fakultatif anaerob yang dapat hidup pada kondisi aerob maupun anaerob sehingga tidak berpengaruh pada viabilitas BAL yang terkandung didalamnya. Penelitian dapat disimpulkan bahwa isi rumen kering masih terdapat koloni BAL yang dapat digunakan sebagai alternatif dalam pembuatan silase untuk mempercepat ensilase.
\end{abstract}

Kata kunci: Isi rumen segar, isi rumen kering, total BAL, inokulan

How to Cite:

Anifiatiningrum., Marjuki., \& Chuzaemi, S. (2020).

Total Bakteri Asam Laktat Isi Rumen Kering dan

Segar Sebagai Inokulan dalam Pembuatan Silase.

Jurnal Nutrisi Ternak Tropis 3 (1) 14-17
*Corresponding author:

Anifiatiningrum

Email: ningrumanifiati@gmail.com

Fakultas Peternakan, Universitas Brawijaya Jalan

Veteran, Ketawanggede, Kec. Lowokwaru, Kota Malang, Jawa Timur, Indonesia 65145 


\section{ABSTRACT}

The purpose of this research was to determine the total of lactic acid bacteria (LAB) contained in the dried rumen content by observing the total LAB of fresh and dried rumen content. The rumen contents are taken from 8 cattles taken from the rumen contents after they are mixed (composite) homogeneously from the 8 cattles. The variables observed were total $L A B$ of fresh and dried rumen content. The results showed of this reaserch on total LAB of fresh rumen content didn't significantly different to the total LAB of dried rumen content, because in dried rumen content there are still facultative anaerobic bacteria that can live in aerobic or anaerobic conditions so it didn't significantly different in viability of LAB contained therein. The conclusion of this reaserch was the dried rumen content still contained $L A B$ colonies can be used as an alternative to the inoculant subtitution of the fresh rumen content in making silage to speed up the ensilase process.

Keywords: Fresh rumen content, dried rumen content, total LAB, inoculant

\section{PENDAHULUAN}

Bakteri asam laktat (BAL) mempunyai peranan penting sebagai penunjang proses ensilase pada silase. Peningkatan kualitas silase diperlukan adanya penambahan inokulan berupa BAL dalam proses ensilase. Inokulan adalah mikroorganisme minimal 1 atau lebih yang akan ditambuhkan ke substrat atau media untuk menghasilkan produk fermentasi. Isi rumen sapi duduga masih terdapat BAL yang terkandung didalamnya, oleh karena itu isi rumen sapi dapat dijadikan sebagai inokulan dalam pembuatan silase. Isi rumen sapi dari RPH masih belum dimanfaatkan, tetapi dibiarkan menumpuk dan membusuk di Instalasi Pengolahan Air Limbah (IPAL) yang mengalir di sungai sehingga menyebabkan pencemaran lingkungan (Abouheifk, Kraidees and Al-Selbood, 2014). Berat isi rumen segar yaitu 24,5 $\mathrm{kg} /$ ekor atau $3,8 \mathrm{~kg}$ BK/ekor, karena mengandung BK 15,5\% (Witherow and Lammers, 1976 cit. Utomo, Yusiati, Umiyasih, Aryogi dan Isnandar, 2007). Jenis bakteri yang terkandung di dalam isi rumen yaitu bakteri pembentuk asam, lipolitik, amilolitik, proteolitik, dan selulolitik (Sutrisno, 1994).

Isi rumen sapi dengan kondisi segar memiliki kelemahan yaitu memiliki bau khas amoniak $\left(\mathrm{NH}_{3}\right)$ yang sangat kuat, memiliki tekstur yang lembek, memiliki kadar air yang sangat tinggi, hanya dapat disimpan jangka waktu pendek dan tingginya gas metan dapat mengakibatkan pemanasan global. Solusi yang tepat untuk mengatasi hal tersebut yaitu dengan alternatif proses pengolahan isi rumen segar dengan metode pengeringan. Pengeringan matahari merupakan pendekatan yang sangat baik untuk masalah pengeringan isi rumen (Khattab, Gado, Kholif, Mansour and Kholif, 2011). Proses pengeringan isi rumen segar bertujuan untuk menghilangkan bau khas amoniak $\left(\mathrm{NH}_{3}\right)$, memperbaiki tekstur menjadi remah, meningkatkan palatabilitas, mempertahankan dan meningkatkan kandungan nutrisi serta diharapkan dapat disimpan dalam jangka panjang. Hasil penelitian ini diharapkan mampu meningkatkan proses ensilase pada silase dengan adanya penambahan inokulan isi rumen sapi dengan metode pengeringan.

\section{MATERI DAN METODE}

Materi yang digunakan dalam penelitian ini adalah isi rumen sapi diperoleh dari PD. RPH Kota Malang yang beralamat di Jalan Kolonel Sugiyono No.176 Malang. Berikut ini adalah 8 ekor sapi yang diambil isi rumennya ditampilkan pada Tabel 1 . Pengambilan isi rumen sapi dari beberapa jenis sapi yang tertera pada Tabel 1 sebanyak 8 ekor sapi dilakukan setelah sapi dipotong dengan pengambilan masing- 
masing sebanyak $2 \mathrm{~kg}$ dan langsung dimasukkan wadah. Kemudian dilakukan penangan isi rumen segar dan kering dengan metode sebagai berikut: 1.Penanganan isi rumen sapi segar Penanganan isi rumen segar dilakukan dengan cara memasukkan sampel isi ruemen segar kedalam masingmasing pot film sebanyak 2 gram pada masing-masing ekor sapi. Setelah itu dilakukan pencampuran isi rumen segar dari 8 ekor sapi secara homogen. Kemudian dilakukan pengujian analisis total BAL yang terkandung di dalam isi rumen segar. Penanganan isi rumen kering dilakukan dengan metode (Broderick, 1985). Metode ini dilakukan dengan cara sampel isi rumen dimasukkan oven 60o C selama 2-3 hari. Setelah pengeringan sampel isi rumen selesai, kemudian dilakukan penggilingan. Tahap selanjutnya dilakukan pencampuran isi rumen kering dari 8 ekor sapi secara homogen. Kemudian dilakukan pengujian analisis total BAL yang terkandung di dalam isi rumen kering.

Tabel 1. Jenis sapi yang terdiri dari 8 ekor yang diambil isi rumennya.

\begin{tabular}{cccc}
\hline Jenis Sapi & Bobot Badan $(\mathrm{kg})$ & Umur Sapi (tahun) & Jenis Pakan yang diberikan \\
\hline Limousin & 550 & $2,5-3$ & Pakan Finisher \\
Limousin & 550 & $2,5-3$ & Pakan Grower \\
Limousin & 590 & $2,5-3$ & Pakan Grower \\
Brangus & 530 & 4 & Pakan Grower \\
Limousin & 600 & $2,5-3$ & Dominan Pakan Hijauan \\
Limousin & 600 & 4 & Dominan Pakan Hijauan \\
Limousin & 500 & $2,5-3$ & Dominan Pakan Hijauan \\
Brangus & 600 & 4 & Dominan Pakan Hijauan \\
\hline
\end{tabular}

\section{HASIL DAN PEMBAHASAN}

\section{Kandungan total BAL isi rumen}

Data yang ditampilkan pada Tabel 2 menunjukkan bahwa total BAL isi rumen segar dan isi rumen kering tidak memiliki perbedaan signifikan. Hal ini dipengaruhi oleh mikroorganisme yang bersifat fakultatif anaerob yang dapat hidup dalam kondisi aerob maupun anaerob. Hal tersebut terbukti bahwasanya pengeringan isi rumen kering tidak berpengaruh pada viabilitas. Hasil penelitian Damayanti, Sakti, Karimy, Herdian, Julendra, Sofyan dan Istiqomah (2006), hasil total BAL yang hidup pada isi rumen sapi berfistula pernakan ongole setelah dilakukan spray drying sejumlah 9,1 $\log \mathrm{cfu} / \mathrm{ml}$ (isi rumen segar) dan 8,9 log $\mathrm{cfu} / \mathrm{ml}$.

Hasil tersebut lebih tinggi dibandingkan dengan total BAL isi rumen kering pada penelitian ini. Jenis sapi, proporsi pakan dan jenis pakan yang diberikan pada ternak yang diuji. Cahyaningtyas, Kusmartono dan Marjuki (2019) menyatakan bahwa total BAL pada isi rumen dipengaruhi oleh pakan yang diberikan (rasio hijauan dan konsentrat), komposisi bakteri dan kondisi fermentasi di dalam rumen.

Tabel 2. Total BAL isi rumen segar dan kering

\begin{tabular}{lc}
\hline Inokulan & Total BAL $(\log$ cfu/gr BK) \\
\hline Isi rumen segar & 3,88 \\
Isi rumen kering & 3,80 \\
\hline
\end{tabular}

Sumber: Laboratorium Hama dan Penyakit Tanaman, Fakultas Pertanian, Universitas Brawijaya, Malang (2019).

Penelitian yang dilakukan Winurdana (2016), penambahan isi rumen segar dan bahan aditif sumber karobihidrat (bekatul dan tepung gaplek) menghasilkan penurunan $\mathrm{pH}$ yang sangat cepat dan menghasilkan produksi asam laktat yang 
tinggi. Hal ini didukung oleh penelitian Utomo, Budhi dan Astuti (2013), pembuatan silase isi rumen sapi pada level $15 \%$ dengan penambahan bahan aditif berupa onggok

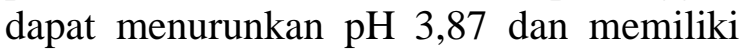
nilai fleigh 98,58 (sangat baik).

\section{KESIMPULAN DAN SARAN}

Koloni BAL masih terdapat dalam isi rumen kering sehingga dapat digunakan sebagai alternatif pengganti inokulan isi rumen segar dalam pembuatan silase untuk mempercepat ensilase.

\section{DAFTAR PUSTAKA}

Abouhief, M. A., Kraidees, M. S., \& AlSelbood, B. A. (1999). The Utilization of rumen content-barley meal in diets of growing lambs. Asian-Australasian Journal of Animal Sciences, 12(8), 1234-1240. https://doi.org/10.5713/aj as.1999.1234

Broderick, G. A. (1985). Alfalfa silage or hay versus corn silage as the sole forage for lactating dairy cows. Journal of Dairy Science, 68(12), 3262-3271. https://doi.org/10.3168/jd s.S0022-0302(85)81235-2

Cahyaningtyas, Z., Kusmartono, K., \& Marjuki, M. (2019). Sintesis Protein mikroba rumen dan produksi gas in vitro pakan yang ditambah urea molasses block (UMB) yang mengandung ragi tape sebagai sumber probiotik. Jurnal Nutrisi Ternak Tropis, 2(2), 38-46. https://doi.org/ 10.21776/ub.jnt.2019.002.02.2

Damayanti, E., Sakti, A. A., Karimy, M. F., Herdian, H., Julendra, H., Sofyan, A., \& Istiqomah, L. (2006). Penapisan Bakteri Asam Laktat Asal Rumen Sapi dan Kambing sebagai Probiotik dan Viabilitasnya selama Proses Spray Drying dan Penyimpanan. In Prosiding Seminar Paparan IPT (pp.
261-272). Yogyakarta: Kedeputian IPT LIPI.

Khattab, H. M., Gado, H. M., Kholif, A. E., Mansour, A. M., \& Kholif, A. M. (2011). The potential of feeding goats sun dried rumen contents with or without bacterial inoculums as replacement for berseem clover and the effects on milk production and animal health. International Journal of Dairy Science, 6(5), 267-277. https:// doi.org/10.3923/ijds.2011.267.277

Sutrisno, C. L. (1994). Proceeding Seminar Nasional Sains dan Teknologi Peternakan Pengolahan dan Komunikasi Hasil-Hasil Penelitian Ternak. Ciawi.

Utomo, R., Budhi, S. P. S., \& Astuti, I. F. (2013). Pengaruh level onggok sebagai aditif terhadap kualitas silase isi rumen sapi. Buletin Peternakan, 37(3), 173-180. https://doi.org/10.21 059/buletinpeternak.v37i3.3089

Utomo, R., Yusiati, L. M., Umiyasih, U., \& Isnandar, A. (2007). Pemanfaatan Isi Rumen Limbah Rumah Potong Hewan Sebagai Pakan Alternatif Pengganti Hijauan. Kerjasama UGM Yogyakarta dengan Badan Penelitian dan Pengembangan Pertanian Jakarta.

Winurdana, A. S. (2016). Pemanfaatan Inokulan Isi Rumen Sapi Yang Dikombinasikan Dengan Bahan Aditif Terhadao Kualitas Fisik dan Kimia Hijauan Jagung (Zea mays). Malang: Fakultas Peternakan Universitas Brawijaya. 